\title{
Amino Acid Activation and Formation of Amino Acyl s-RNA in Bovine Parotid Gland
}

\author{
by \\ Hisashi TAKIGUCHI,* Shunsuke FURUYAMA,* \\ Yotaro OGATA* and Jiro KANNO*
}

\begin{abstract}
Introduction
Our previous report described the general characteristics of cell-free amino acid incorporating system consisting of bovine parotid gland microsome and cell sap [4]. The requirement of adenosine triphosphate (ATP), guanosine triphosphate (GTP) and cell sap for the maximal incorporation in the cell-free system may indicate that the general pathway of the protein biosynthesis, amino acid activation, amino acyl soluble ribonucleic acid (amino acyl s-RNA) formation and transfer of amino acid to microsomes, may operate in this system.

However, there has been no study on each step by which this protein biosynthesis takes place in parotid gland.

In an attempt to elucidate in detail the each step in protein biosynthesis of parotid gland, the following experiments were carried out; Experiments on the amino acid activation and amino acyl s-RNA formation in parotid gland cell-free system.

$\mathrm{P}^{32}$-labeled pyrophosphate $\left(\mathrm{PP}^{32}\right)$ was prepared by the method of KorNBERG and PrICER[7] and purified by the modified procedure of COHN and CARTER[1]. The preparation of microsome and soluble fraction from parotid gland was carried out as described in the previous paper[4].
\end{abstract}

Assay Method of Amino Acid Activating Activity

One ml. of incubation mixture for the PP${ }^{32}$-ATP exchange assay contained 3 $\mu$ moles of ATP, $3 \mu$ moles of PP $^{32}$ (about 100,000 counts/minute by Geiger-Müller

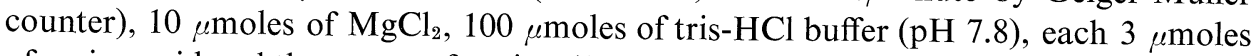
of amino acid and the enzyme fraction ( $1 \mathrm{mg}$. of protein). The cell sap, pH 5.2 fraction, $\mathrm{pH} 4.5$ fraction and $\mathrm{pH} 4.5$ supernatant fraction prepared by the method of SATAKE et al. [9], were used respectively as the enzyme fraction. After incubation at $37^{\circ} \mathrm{C}$ for 15 minutes, the reaction was stopped by addition of $2.0 \mathrm{ml}$. of $7.5 \%$-trichloroacetic acid and $\mathrm{PP}^{32}$ and ATP were separated by adsorption on charcol according to the method of CRANE and Lipmann[2].

The concentration and radioactivity of ATP and pyrophosphate were determined as inorganic orthophosphate after hydrolysing these compounds in $0.7 \mathrm{ml}$. of $1 \mathrm{~N} \mathrm{HCl}$ at $100^{\circ} \mathrm{C}$ for 10 minutes. Inorganic phosphate was determined by the method of FISKE and SubBarow[3].

*滝口久, 古山俊介, 尾形容太郎, 菅野次郎, Dept. of Biochemistry, Nihon Univ. School of Dentistry, Surugadai, Chiyoda-ku, Tokyo, Japan. 
The radioactivity was measured with a Geiger-Müller counter. The data were expressed as per cent exchange according to HoAGLAND et al.[5].

\section{Assay Method for Incorporation of Labeled Amino acid into s-RNA}

Two $\mathrm{ml}$. of the reaction mixture contained $\mathrm{pH} 4.5$ fraction (about $12 \mathrm{mg}$. of protein), $5 \mu$ moles of ATP, $7.5 \mu$ moles of $\mathrm{MgCl}_{2}, 37.5 \mu$ moles of $\mathrm{KCl}, 375 \mu$ moles of sucrose, $75 \mu$ moles of tris- $\mathrm{HCl}$ buffer ( $\mathrm{pH} 7.6$ ) and $20 \mathrm{~m} \mu$ moles of uniformly labeled $\mathrm{C}^{14}$-L-valine ( 66 mcuries/mmole). After incubation at $37^{\circ} \mathrm{C}$ for 15 minutes, the reaction mixture was diluted with $4 \mathrm{ml}$. of cold distilled water and made to $\mathrm{pH} 4.5$ with 0.1 $\mathrm{N}$ acetic acid at $\mathrm{O}^{\circ} \mathrm{C}$. The precipitate formed was separated by centrifugation and washed with $8 \mathrm{ml}$. of cold water of $\mathrm{pH} 4.5$ (adjusted with acetic acid) by homogenization followed by centrifugation, then dissolved in $7 \mathrm{ml}$. of medium A which was prepared according to the method of LiTTLEFIELD and Keller[8], and s-RNA was isolated from the solution with carrier RNA ( $5 \mathrm{mg}$. of yeast RNA) by the phenol treatment followed by ethanol precipitation as described by HoAGLAND et al.[6].

The RNA fraction obtained was transfered into an aluminum dish, dried under infrared light, and its radioactivity was measured by a gas flow counter.

The amino acid activation by the cell sap of bovine parotid gland was studied by $\mathrm{PP}^{32}$-ATP exchange reaction in the presence of $10 \mathrm{mM}$ of $\mathrm{NaF}$ to inhibit adenosine triphosphatase [EC 3.6.1.4.] and pyrophosphatase (EC 3.6.1.1.) activity completely. In the cell sap, high $\mathrm{PP}^{32}$-ATP exchange was found in the presence of amino acid mixture, and some activity was determined in the absence of amino acid mixture as shown Table 1.

Dialysis of cell sap against redistilled water resulted in reduction of PP $^{32}$-ATP exchange activity in the absence of amino acid mixture (Table 1). After heating of the cell sap at $60^{\circ} \mathrm{C}$ for 5 minutes, $\mathrm{PP}^{32}$-ATP exchange activity was decreased considerably and even after heating at $90^{\circ} \mathrm{C}$ for 5 minutes the activity was negligible (Table 1).

Table 1. Amino acid dependent $\mathrm{PP}^{32} \mathrm{ATP}$ exchange by cell sap

\begin{tabular}{|c|c|c|c|c|}
\hline & \multicolumn{2}{|c|}{ Exp. 1} & \multicolumn{2}{|c|}{ Exp. 2} \\
\hline & \multicolumn{2}{|c|}{ Amino acid mixture } & \multicolumn{2}{|c|}{ Amino acid mixture } \\
\hline & + & - & + & - \\
\hline Non-dialyzed & 17.5 & 12.0 & 20.9 & 15.3 \\
\hline Dialyzed & 14.9 & 2.4 & 15.0 & 2.5 \\
\hline Dialyzed and heated & & & & \\
\hline at $60^{\circ} \mathrm{C}$ for $5 \mathrm{~min}$. & 1.9 & & 2.1 & \\
\hline at $90^{\circ} \mathrm{C}$ for $5 \mathrm{~min}$. & 0 & & 0 & \\
\hline
\end{tabular}

It was found that the cell sap and its subfraction had a high PP $^{32}$-ATP exchange activity, and among three subfraction of cell sap, the $\mathrm{pH} 4.5$ fraction had the highest activity and the $\mathrm{pH} 4.5$ supernatant fraction was almost inactive (Table 2).

The results of the experiments, in which individual amino acid dependent PP ${ }^{32}$-ATP exchange activity was determined, indicate that the PP32-ATP exchange activity by dialysed cell sap was increased significantly by isoleucine, valine, threonine and 
tryptophan and moderately increased by histidine, lysine and phenylalanine, while hydroxyproline, arginine, glutamic acid, glycine, aspartic acid, methionine, alanine, proline and leucine had little or no effect as shown Table 3.

In the experimental conditions described above, incorporation of $\mathrm{C}^{14}$ - $\mathrm{L}$-valine into s-RNA in the pH 4.5 fraction was observed (Table 4).

Table 2. PP $^{32}$-ATP exchange activity of subfraction of cell sap

\begin{tabular}{|l|cc|cc|}
\hline & \multicolumn{2}{|c|}{ Exp. 1 } & \multicolumn{2}{c|}{ Exp. 2 } \\
\cline { 2 - 4 } & $\begin{array}{c}\text { Amino acid mixture } \\
+\end{array}$ & - & \multicolumn{2}{c|}{$\begin{array}{c}\text { Amino acid mixture } \\
+\end{array}$} \\
\hline cell sap & 17.6 & 4.2 & 19.8 & - \\
pH 5.2 fraction & 25.7 & 3.4 & 25.0 & 2.8 \\
pH 4.5 fraction & 41.0 & 12.3 & 41.2 & 10.5 \\
pH 4.5 supernatnt & & & & \\
fraction & 10.6 & 2.8 & 8.9 & 2.5 \\
\hline
\end{tabular}

( $\% / \mathrm{mg}$. of protein)

In this experiment, the cell sap used was dialyzed against redistilled water.

Table 3 .

Efficiency of individual amino acid on PP32-ATP exchange by cell sap

\begin{tabular}{|l|r|r|r|}
\hline & Exp. 1 & Exp. 2 & Exp. 3 \\
\cline { 2 - 3 } Amino acid mixture & & & \\
\cline { 2 - 3 }$(+)$ & 16.9 & 45.9 & 31.5 \\
Hydroxyproline & 2.2 & 7.2 & 5.2 \\
Arginine & 2.3 & 6.6 & 6.3 \\
Histidine & 2.2 & 7.0 & 6.2 \\
Glutamic acid & 5.2 & 8.4 & 8.6 \\
Glycine & 2.3 & 7.0 & 6.1 \\
Isoleucine & 3.4 & 5.0 & 5.9 \\
Valine & 4.7 & 13.5 & 8.8 \\
Lysine & 6.4 & 10.1 & 9.0 \\
Aspartic acid & 4.9 & 9.7 & 6.8 \\
Methionine & 3.8 & 9.0 & 7.3 \\
Alanine & 4.2 & 4.9 & 5.5 \\
Threonine & 3.7 & 7.3 & 6.9 \\
Phenylalanine & 8.8 & 20.9 & 15.9 \\
Tryptophan & 3.7 & 10.1 & 7.5 \\
Proline & 6.8 & 15.1 & 10.1 \\
Leucine & 2.4 & 10.9 & 6.1 \\
\hline & 3.5 & 7.2 & 6.2 \\
\hline
\end{tabular}

( $\% / \mathrm{mg}$. of protein)

In this experiment, the cell sap used was dialyzed against redistilled water. 
Table 4.

Incorporation of $\mathrm{C}^{14}$-L-valine into s-RNA

by $\mathrm{pH} 4.5$ fraction

\begin{tabular}{|c|c|}
\hline Exp. No. & Total c.p.m. of s-RNA \\
\hline 1 & 1096 \\
2 & 1141 \\
3 & 1447 \\
\hline
\end{tabular}

\section{Conclusion}

The present experiments suggest that the protein biosynthesis by the cell-free system of bovine parotid gland may consist of a sequence of the following steps: amino acid activation, formation of amino acyl s-RNA, and transfer of amino acid from s-RNA to microsomes. But, in this experiment, we did not demostrate the last step, which is, transfer of amino acid from s-RNA to microsomes.

\section{References}

[1] Cohn, W. E. and CARTER, C. E.: The separation of adenosine pyrophosphates by ion exchange and paper chromatography; J. Amer chem.. Soc., Vol. 72, 4273-4275, 1950.

[2] Crane, R. K. and Lipmann, F.: The effect of arsenate on aerobic phosphorylation; J. biol. Chem., Vol. 201, 235-243, 1953.

[3] Fiske, C. H. and Subba Row, Y.: The colormetric determination of phosphorus; J. biol. Chem., Vol. 66, 375-400, 1925.

[4] Furuyama, E., Furuyama, S., Takiguchi, H., and Kanno, J.:Protein biosynthesis in a cell-free system of the bovine parotid gland. Part 1 . Incorporation in vitro of glycine-2- $\mathrm{C}^{\mathbf{1 4}}$ into protein by parotid gland microsomes; J. Nihon Univ. Sch. Dent., Vol. 9, 24-30, 1967.

[5] Hoagland, M. B., Keller, E. B. and ZamecniK, P. C.: Enzymatic carboxy activation of amino acids; J. biol. Chem., Vol. 218, 345-358, 1956.

[6] Hoagland, M. B., Stephenson, M. L., Scott, J. F., Hecht, L. I. and Zamecnik, P. C.: A soluble ribonucleic acid intermediate in protein synthesis; J. biol. Chem., Vol. 231, 241-257, 1958.

[7] Kornberg, A. and Pricer, W. E.: Enzymatic cleavage of diphosphopyridine nucleotide with radioactive pyrophosphate; J. biol. Chem., Vol. 191, 535-541, 1951.

[8] Littlefield, J. W. and Keller, E. B.: Incorporation of $\mathbf{C}^{\mathbf{1 4}}$-amino acid into ribonucleoprotein particles from the Ehrlich mouse ascite tumor; J. biol. Chem., Vol. 224, 13-30, 1957.

[9] Satake, M., Takahashi, Y., Mase, K. and Ogata, K.: Protein biosynthesis in a cell-free system of the guinea pig brain. (1) Incorporation in vitro of $\mathrm{C}^{\mathbf{1 4}}$-leucine into protein by brain microsomes; J. Biochem., Vol. 46, 504-511, 1964. 